\title{
Effect of Smallholder Tea Growing on Food Crop Production in Bomet County, Kenya, 1954-1963
}

\author{
Chepkemoi Kirui Fancy C.* \\ Department of History, Archeology and Political Science, Kenyatta University, Kenya
}

\author{
*Corresponding Author: Chepkemoi Kirui Fancy C., Department of History, Archeology and Political \\ Science, Kenyatta University, Kenya
}

\begin{abstract}
The research investigated smallholder tea production and its effects in Konoin, Bomet County, Kenya, from 1954 to 2002. Based on the study, this paper examines the effects of smallholder tea production on food crop production in Konoin, Bomet County from 1954 to 1963. The study adopted a descriptive research design. Purposive sampling technique was used to identify the informants with vital information. These included farmers, and those practicing tea related activities sampled from the study area. These included the people who witnessed the introduction of tea growing in Konoin Bomet County. The data collection used the study were interview schedule and observation schedule. Data analysis entailed corroboration of secondary data with primary data. Finally, data was presented qualitatively. The research found that cash crop production negatively impacted on food production. The study has shown that negative effects of cash crops occur when too much land is put under cash crops and little under food crops. Too much time was also allocated to tea and its elaborate activities and on the other hand food production was neglected. This was because plucking of tea was done every day mostly by women making it difficult for farmers to leave tea picking to cultivate food crops. In addition, farmers spent a lot of time at the tea buying centres waiting for transport which did not allow them to engage in any other economic activities. Consequently, most of the food consumed in the district was bought from the market. Any changes in the food market affected the area of study either positively or negatively in terms of prices. The study found that granaries once used for food harvest had been turned into stores for farm tools. This dependence on tea production ultimately undermined food sustainability in Konoin.
\end{abstract}

Keywords: Smallholder Tea Growing, Food Crop Production, Bomet County, Kenya, 1954, 1963

\section{INTRODUCTION}

Tea farming in Kenya was introduced mainly by the colonial regime of the British. After the Second World War, Britain was exhausted, having suffered immense material and manpower loss during the war. Therefore, the country was compelled to heed the demands of the USA with regard to granting political independence to her subjects. Apart from this, the United Nations Organization which was created in 1945 also contributed to the process of decolonization (Ochieng, 1989). The war experiences made the colonial peoples to become politically conscious. It is argued that the period following the Second World War was characterized by radical African nationalist activities. Despite all these, the colonial state policy continued to favour the white settler sector of the economy. In the African reserves shortage of land was becoming an issue. This land shortage was worst in central Kenya among the Agikuyu. Forced labour and heavy taxation, poor housing conditions explains the reason for the growth of militant trade unionism in Nairobi and Mombasa.

It was against this background that Mau Mau movement began in the second-half of the 1940s. The situation worsened in Central Kenya and Rift Valley where arson on white farms was reported. The Governor, Sir Evelyn Baring, was posted to Kenya in the same year and he first toured Central Province. He was convinced that a state of anarchy was brewing in the country. Baring concluded that a state of emergency was the only measure of saving the situation. He was granted permission by the secretary of colonies to declare a State of Emergency on $10^{\text {th }}$ October 1952 following the assassination of prominent African loyalists and attacks on white settler farms in central Kenya (Ochieng, 1989; Maloba, 1993).

Under the emergency measures the colonial government decided to carry out major economic reforms. This was because during this period, the government acquired immense powers to carry out physical brutal war against Mau Mau supporters. Major economic reforms were also put in place in 
order to discourage and do away with local Mau Mau support (Ochieng, 1989). Mau Mau movement resulted in the realization that the settlers were incapable of ruling the country. Secondly, a number of commissions were set up to find out the economic situation in Kenya. These included the East African Royal Commission (1953), the Swynnerton Plan of 1954 and the Lind Bury Commission. The East African Royal Commission called for decolonization of the white highlands while the Swynnerton Plan recommended for registration and consolidation with a view to giving African land titles. On the other hand, the Lind Bury Commission called for an increase in African participation in civil service. This was followed by constitutional changes (Ochieng \& Ogot, 1995).

The major reform was the land consolidation programme which was conceived by Swynnerton who was the assistant director of agriculture (Leys, 1994). He was previously very instrumental in encouraging peasant agriculture in Tanganyika (MacKenzie, 1999). The Swynnerton Plan which was released in 1954 intensified the development of African agricultural policy in Kenya (Leys, 1994). This policy was published in 1954 and it gave a comprehensive change of African agriculture from what the government termed 'a circle of subsistence or near subsistence agriculture' (Lipscomb \& Winston, 1972).

The objective of the Plan was to promote the growth of small African capitalists through improved productivity. The plan recommended the growth of cash crops by land owners. The plan assumed twenty years would be needed to implement it. Coffee was to expand by 5,000 new acres per year targeting 71,000 acres by the year 1968 (Swynnerton, 1954). On the other hand, tea was expected to reach 70,000 acres by the same year while pyrethrum was expected to reach 48,300 acres (Swynnerton, 1954). The plan was intended to change African pre-capitalist production in Kenya to capitalist model of production. Consequently, Africans were allowed to grow cash crops and engage in smallholder farming (Odingo, 1971). Initially, this had been the preserve of the whites. The Plan also found it necessary for land to be privatized in order to promote an intensive type of agriculture. According to the Plan, land consolidation, registration and enclosure was necessary for an intensive agriculture (Swynnerton, 1954). This increased land adjudication and privatization in all African reserves. The Swynnerton Plan sought to create a stable land owning class with access to capital and income from growing of cash crops which had been predominantly grown by Europeans. In this sense, therefore, the Swynnerton Plan increased access to land governed by a codified law that favoured men who were highly placed in society at the expense of the poor (Elkins, 2005).

Among the Kipsigis of present-day Konoin Sub-County, Bomet County, the beneficiaries of the Swynnerton Plan were those who had converted to Christianity and those who were lucky to be appointed as leaders in the Government (Personal Communication, Tobon, 2013). These people allocated themselves massive pieces of land. The members of African Inland Church and African Inland Mission through the leader's campaign were among the first Africans to adopt tea production (Personal Communication, Soi, 2013). According to Soi, the Kipsigis Christian converts, a privileged group, acquired the name meskenek which was a term used to refer to those who converted to Christianity by other members of the community.

The Swynnerton Plan proposed the development of planned farming and introduction of cash crops to raise living standards and to provide finance for farm development. According to the Plan, there was to be a provision of staff and training on how to take care of the special cash crop. It was estimated that the long-term target for tea development in the African land units was to be developed by the years 1968 and 1970 respectively (KNA/AGR/KSM/1984). The Swynnerton Plan gave a proposal that the Kipsigis smallholder tea growing scheme be started at Kimulot area in Konoin, Bomet County. In connection to this plan, the Nyanza Provincial agricultural Officer wrote to the director of agriculture Nairobi suggesting that the first controlled tea growing scheme be started at Kimulot Settlement Scheme (KNA/AGR/KSM/1984).

The Tea Board was asked if the tea companies, James Finlays and Brooke Bond would be prepared to purchase tea leaves produced by the Africans (KNA/AGR/KSM/1984). The tea companies refused giving reasons that purchase of leaf would encourage Africans to steal leaf from European owned tea estates. Besides, the companies argued, the factories had been planned to capacity and that erecting new factories would be costly. Furthermore, transport would be a challenge because of the distance from African farms and European tea estates would be denied African labour (KNA/AGR/KSM/ 1984). 
To ensure that the process of introducing tea was smooth, the Tea Board of Kenya had been established in June 1950 as a State Corporation through an Act of Legislative Council under the Department of Agriculture (Swainson, 1980). It was given the mandate to regulate tea industry in Kenya which was in accordance with general or special directions given to it by the Minister for Agriculture. Swainson adds that it was also given the duty to license tea growers and tea factories, establish factories, control pests and diseases, control cultivation of tea, processing, exporting of tea and conducting research. The body provided advice on policy matters concerning tea. The chairman of TBK was appointed by the minister from among the tea producers (KNA/TBK/1950). TBK was not ready to allow Africans to grow tea and explained that this would give rise to theft of leaf by Africans from European owned tea estates. Members of the TBK also argued that the existing tea factories were already planned to capacity and therefore new factories were needed. Distance from the factories was also cited as a major problem that would be experienced in addition to shortage of labour for European tea estates if Africans were to be allowed to produce tea (KNA/TBK/1950). Therefore the opinion of the tea industry stakeholders was that there was going to be more chances of success if African grown tea was allowed to be established on large acreage and provided with its own central factory (KNA/TBK/1950).

\subsection{Effect of Smallholder Tea Production on Food Crop Production}

Ochieng and Ogot (1995), in their historical study, observe that post-independent Africa kept increasing its cash crop production to earn foreign exchange. Transport, infrastructure and technical assistance have been directed towards reviving cash crops. As Africa has invested more heavily on cash crops, per capital food production has declined. They note that even during drought, some African countries managed to increase their total harvest of cash crop. The reasons given include the value of cash crops as compared to other crops. This value is in terms of money earned through the sale of these crops. Ochieng and Ogot studied cash crops generally and the attention that has been given. This research, however, focused on smallholder tea production in Konoin and how it has impacted on food crop production and standards of living.

Isaacman (1996) has studied cotton production in Portuguese Mozambique and argues that just like in East and Central Africa, colonial planners in Mozambique initially assumed that cotton had to be a white man's crop. He reports that there was a general agreement that plantations worked by Africans under the immediate supervision by Europeans would yield the highest returns. Since expanded crop production was the primary objective, there was a strong tendency to entice rural population to take up cotton cultivation. The efforts of the Portuguese to transform African farming practices were perhaps misguided especially with the ban on intercropping cotton with household food crops. Their main aim was to protect cotton from competing with other crops. The peasants had every reason to be distrustful because of the low yields and artificially depressed prices which left most of the households economically impoverished. Isaacman's study further demonstrates that cotton rendered Africans in Mozambique poor as it demanded a great deal in terms of inputs and offered little in return. Cotton production therefore led to food shortages hence poverty. Isaacman researched on cotton in Uganda while this research focused on smallholder tea in Konoin, Bomet County.

Njogu (2002), in a scientific study on household food security and nutritional status of children in tea and non-tea producing households in Kirinyaga District, notes that tea payments were usually made monthly and annual bonus given at the end of the year. Tea production on small land holdings did not yield high levels of income as large holdings would do. Tea producing households gave first priority to the purchase of food when they received their money. The reason food was given the first priority was because these households did not get enough food through home production and therefore had to purchase from the market. Njogu further asserts that most of the farmers in the tea producing areas devoted most of their land to tea production at the expense of food. In terms of houses, tea producing households had better houses than the non-tea producing ones. Njogu studied tea production in relation to food production in Kirinyaga District. The present study focused on smallholder tea production and its effect on food production in Konoin, Bomet County.

Langat, Ngeno, Sulo, Nyangweso, Korir, Kipsat and Kebenei (2011), in their agricultural economic studies, assert that majority of farmers in Nandi South District faced food shortage in the months of April, May, June and July and only got accessed to food through markets. These markets are largely dependent on the tea incomes. Tea production and maize production competed together for land resource in the District. Generally, tea production took a dominant position among these farmers. 
Majority of the farmers preferred cash crops and hence more land was put on tea production and less on maize production. These ideas were very important to this research particularly, on the issue of farmers adopting cash crop production at the expense of food crop production. Langat et al. focused on the effects of tea production on food production in Nandi South District. This paper derives its discussion from Konoin Sub-County in Bomet County.

Njiru (1982) has conducted gender studies on the effects of tea production on women's work and labour allocation in Embu District. In her study, she found out that agricultural activities led to socioeconomic differentiations. She further added that a lot of labour was directed to tea production as opposed to livestock keeping and food production. However, despite the fact that this increased the work load for women, on the other hand it increased their income. Her work focused on the effects of tea production on women's work. This study examined the effect of smallholder tea on food production in Konoin, Bomet County.

Odhiambo, Nyangito and Nzuma (2004) and Kabura (2005) aver that declining living standards and poverty was evident among many rural families in Murang'a that for a long time depended on cash crops as a major source of income. What farmers earned from cash crops such as tea declined due to competition in the global market and changes in consumer's tastes among other factors. At the same time, population brought conditions of large family sizes and small farm sizes which impacted negatively on food production. Odhiambo, Nyangito and Nzuma also argue that there was overuse of available land which coupled with drastic changes in climatic conditions led to poor agricultural performance leading to hunger and poverty. The ideas of these researchers were useful to this research. They showed how family size and farm sizes had contributed to a reduction of land under food crop production leading to food insecurity. The study focused on Muranga while this study focused on Konoin, Bomet County between 1954 and 2002.

Ongile (1996) has explored gender and agricultural supply response to structural adjustment programmes on smallholder tea producers in Kericho noted that the standard of living was influenced more by changing economic environment for some household. Tea households had larger farms and more children attending school because of the economic status which they enjoyed as compared to the non-tea producing household who had even sold their land. Her ideas were found to be useful to this study. However, Ongile focused on women while the current research focused on all smallholder tea producers regardless of gender in Konoin Bomet County.

Omwoyo (2000) has studied the agricultural changes in Kipsigisland. He discusses the Kipsigis precolonial methods of animal husbandry and crop production. He further described how the Kipsigis agriculture was transformed from the pre-colonial state and incorporated into the capitalist mode of production. Omwoyo's study was important as it provided an insight on the changes that took place in Kipsigis agricultural systems during colonial period and particularly the period before the introduction of smallholder tea. It formed the basis of understanding the economic organisation of the Kipsigis in this study. However smallholder tea production as one of the agricultural activities among the Kipsigis was not captured adequately in Omwoyo's study, which this study focused on.

\subsection{Statement of the Problem}

Little attempt has been made to provide a systematic discussion on the effects of smallholder tea production on food crop production. Save for Korir's study (1976), generally, there are scanty historical studies on the subject although smallholder tea production is a significant economic activity in Kenya. Tea production has had far reaching consequence on the lives of farmers in Bomet County. The study, therefore, attempted to address the gap of knowledge on smallholder tea production and its effects in Bomet County. The study adopted a historical approach to examine the development of smallholder tea production and how it has affected food crop production.

\section{Materials AND Methods}

This study adopted a descriptive research design to investigate the smallholder tea production in an effort to understand the effects on food production and household differentiation in Konoin SubCounty, Bomet County. There were three administrative Divisions in Konoin Sub-County at the time of study, namely Konoin, Cheptalal and Kimulot. The Sub-County had a total population of 139,114 distributed in an area of 879 square kilometres and had a total of 31,103 households (Kenya National Bureau of Statistics [KNBS], 2010). KNBS, 2010). The area is inhabited by the Kipsigis community 
of the Kalenjin speaking people and other immigrants working in the tea sector. These residents depend largely on land as they are mixed farmers, keeping livestock and growing crops. As a result, putting too much land under smallholder tea production, most of the other income generating activities have been ignored. Much of the population in Konoin depends directly and indirectly on tea for their livelihood. Others are employed in the tea plantations and tea related industries in the nearby areas. The target population for the study comprised women and men who engaged in tea production and activities related to tea production. Administrators in the National and County governments, church leaders, KTDA officials and extension officers were targeted. They were selected from a cross-section of Kimulot and Konoin Divisions of Konoin in order to ensure representativeness of their information /views. Gender composition was put into consideration.

Purposive sampling technique was used to get a representative sample from the highly productive smallholder tea zones in Konoin Sub-County. From the three Divisions, the researcher purposely picked Kimulot and Konoin. The sample was then selected using snowballing sampling method. Informants were identified and introduced to the researcher by contact persons, who were invariably chiefs or village elders. The contact persons were well informed about the smallholder tea production in Konoin. Due to limitation of time and resources the researcher sought to interview a total of 56 informants. These informants came from Kaptebengwet and Kimulot. These informants sampled from the area were those involved in smallholder tea production and related activities. The sample was made up of 28 smallholder tea farmers, 5 tea buying centre workers were sampled, 10 KTDA officials, 5 retired KTDA workers, 3 administration officials and 5 agricultural extension officers.

The study used interview guide and observation schedules as the main tools for collecting data. The Kenya National Archives in Nairobi was consulted to analyse various documents such as district annual reports, agricultural reports, KTDA reports and handing over reports for both colonial and post-colonial officials. These sources constituted important first-hand information. These documents provided historical data on land policies, crop production, labour policies and agricultural policies. In analysing data, qualitative technique was used. Primary data was collected and transcribed. The cumulative data from the primary and secondary sources were synthesized and the resultant data categorized in accordance to objectives of the study. Theoretical probing was adhered to when analysing both data in order to reach a logical descriptive analysis. Primary and secondary data was corroborated to authenticate the data. Data was then classified according to their content and the specific historical time frame within which each event and developments occurred.

\section{RESUltS AND DISCUSSION}

\subsection{African Smallholder Tea Production in Konoin (1957-1963)}

A number of developments laid the foundation for the introduction of smallholder tea production by the Africans in Kenya and particularly in Konoin. The country's political history, with the struggle for independence which gained momentum in the early 1950's, is closely linked to the adoption and development of tea farming in Kenya. This was the period that Africans began to agitate for land rights and also the right to grow tea. In 1950, Mr Gambie, the Provincial Agricultural Officer, gave a directive that tea grown in Kericho should be planted in blocks (KNA/DC/KER/1/30/1930). This meant that a number of families living close would plant tea together to make supervision easy. Scattered plots were perceived to be a contributing factor towards neglect of tea especially in times when the prices were low (KNA/DC/KER/1/30/1930). Neglecting tea was unacceptable as it was viewed as a menace to neighbouring European tea plantations. It was believed that this would cause diseases to spread easily from one farm to another. It was a requirement for tea growers to maintain the quality of tea (KNA/DC/KER/1/30/1950). The Kipsigis of Konoin felt that this arrangement was interfering with the indigenous land organization system. This made some of them not to accept to grow tea as they saw it as a way of losing more of their land to the Europeans (Personal Communication, Siele, 2013). Two companies, namely Finlay and Brooke Bond were mandated by Tea Board of Kenya (TBK) to help in developing tea growing by Africans in Kenya (KNA/DC/KER/1/30/1930).

\subsection{Kimulot Settlement Scheme and Smallholder Tea Production (1957-1963)}

The Kimulot Settlement Scheme was established in Bureti Location, Kericho District which was then part of Nyanza Province. However, Kimulot currently is located in Konoin Sub-County of Bomet County. Kimulot was affected by land alienation during the colonial period. A block amounting to 
approximately 4,500 acres of land had been alienated for European tea production in addition to approximately 4,000 acres to the north east of Kimulot. There was a lot of resistance by the Kipsigis of Kimulot over the loss of this land (KNA/LAN/1/76/1950). Land alienation in this area led to the creation of African Reserves where the Kipsigis were forced to move into. One of the African Reserves was Kimulot. The confinement in the African reserves was resisted by the Kipsigis who began to protest. They sabotaged the work done by the tea companies, including uprooting of European tea in the neighbourhood (Personal Communication, Langat, 2013).

Earlier on in 1954, the Nyanza PC wrote to the Director of Agriculture in Nairobi proposing that the first controlled tea growing scheme be started in Kimulot Settlement Scheme (KNA/AGR/KSM/ 1954). The PC was of the opinion that if the scheme was not going to be successful in the area then there was a possibility that tea growing would not succeed anywhere else in Kenya (KNA/AGR/KSM/1954). The reason for this argument was that Kimulot had all the physical conditions necessary for smallholder tea production.

Before tea could be grown, the tea companies in the area were to give their consent with regard the quality of leaf required and times of delivery (Eden, 1965). These companies which included Brooke Bond and African Highlands were given the role of expanding and improving the cultivation of African smallholder tea. Brooke Bond therefore embarked on an expansion programme which involved both new planting, improvements of plucking and manufacturing techniques (Eden, 1965).

By the end of 1954, Kimulot was found to be suitable for a pilot scheme for the production of tea by the European companies (KNA/DC/KER/1/25/1952). The climate was ideal, leading to the setting up of a small tea nursery (ibid). The seed for the nursery at Kimulot was brought from Tanganyika (East African standard 15/7/1960). Kimulot was selected as the trial area for the first tea planting because plots could be selected close together under high standard supervision by the resident settlement officer. The land where the nursery was set up was originally owned by a Kipsigis man called Arap Borowo who is remembered to have staged a series of resistance to the European rule in the region (Personal Communication, Soi, 2013; Korir, 1976). Majority of the people from Kimulot worked on the nearby tea estates after they lost their land to the Europeans. The Europeans who were already present in the area felt that the farmers needed to grow a valuable cash crop so as to break into higher level of farming (KNA/ DC/KER/1/25/1952).

Consequently, African growers were allowed to put tea on one third of an acre at the start. Seedlings were to be sold to farmers (KNA/DC/KER/1/25/1952). In the beginning it was hard to convince the Kipsigis to accept to plant tea despite the fact that they were already familiar with tea farming having worked on the nearby plantations (East African Standard 12/8/60). Some informants in the area cited various reasons for this. There was a general dislike of tea by the Kipsigis as they felt that tea production was tiresome, that it made the soil to deteriorate and that this was perceived as a way through which the Europeans would take their land (Personal Communication, Binbin, Kogei and Chepkwony, 2013). The production of maize had given them a lesson as it caused soil erosion in the reserves.

After the establishment of smallholder tea scheme at Kimulot, the Tea Board of Kenya was asked if the tea companies could purchase leaf grown in African areas. The companies had a major role to ensure quality control over smallholder tea. This was done through supervision during planting and ensuring that the recommended two leaves and a bud was picked during plucking. Inspection was also done at the collection centres. The growers sold their leaf to the estate company factories of Brooke Bond and Finlay. However, the companies feared that the development of smallholder tea production was going to affect the dominant position they held in tea production. Despite this, Brooke Bond and James Finlay played an important role in shaping the conditions under which smallholder tea scheme developed.

Brooke Bond gave advice on tea growing and also assisted in creating a link between the British machinery suppliers and smallholder tea factories (Swainson, 1980). The stake holders in the tea industry were of the opinion that African tea was to be provided with its own central tea factory if it was to become successful. By 1957, the large European tea growing interests in Kericho District had agreed to process the Kipsigis grown leaf in the factories as they awaited the establishment of African factories (Swainson, 1980). By so doing, tea production continued to be under the monopoly of the Europeans. In addition, the tea companies realised that the African tea needed to be located some 
distance from the established estates in order to discourage the stealing of green leaf from European farms by Africans (Swainson, 1980). The Europeans were opposed to providing additional facilities for the pilot scheme at Kimulot area. This was to avoid competition from African grown tea.

Tea planting by Africans in Nyanza Province therefore began in 1957 with pilot schemes in Kimulot in Bureti Location, Kericho District as mentioned earlier. It was under the supervision of the Department of agriculture which gazetted the area for tea growing by legal Notice No 24 of $13^{\text {th }}$ January 1958 (KNA/NYANZA/2/9/1957). This resulted in about 106 African farmers being allowed to plant tea in the scheme in 1957. This process marked the beginning of smallholder tea production in the area. By working in the nearby estates, Africans acquired a lot of experience in tea production. Each farmer was allowed to plant tea on $1 / 3$ of an acre making a total of $351 \frac{1}{2}$ acres (KNA/DC/KER/1/30/1957; East African Standard 15/7/1960). By 1962 free tea stumps had been issued in Konoin area. African tea development got subsidies from the colonial Government but most of the development expenditure had to be paid for by growers (KNA/NYANZA/2/9/1957).

The reasons given by the informants in the area for accepting the new crops apart from the income they received was that it was mandatory for them to grow tea (Personal Communication, Tobon, 2013). In addition, those who had worked in the European tea estates saw the need to venture in tea production because they wanted to be like the Europeans (Personal Communication, Z. Siele \& J. Siele, 2013). From the oral interviews it was found out that approximately a third of an acre land was allowed to be put under tea by African farmers at the onset. The first smallholders in Konoin sourced the seedlings from Europeans or from the Kabianga seed beds (Personal Communication, Tobon, 2013; Personal Communication, Soi, 2013).

The first plucking of tea in Kimulot was done in 1959 (Korir, 1976). By 1960 tea leaf was taken to Kimari Factory in Konoin for processing. The factory was owned by the European settlers' (Personal Communication, Soi, 2013). As African farmers started to get the financial returns from their tea; they became more interested in the crop (KNA/DC/KER/1/32/1950). The Kipsigis of Konoin were gradually getting integrated into the capitalist world economy. They began to lose their indigenous system of production and begun producing for foreign market which was out of their control.

Before Africans were trained to operate their own factories, management and technical assistance to smallholders was provided by the major tea companies, including Brooke Bond and African Highlands Produce, the subsidiary of Finlay. This influenced the smallholder tea scheme in the growing and processing of tea. They insisted that the smallholder leaf was to be of higher quality than the one of the tea estates. Brooke Bond in particular insisted on this so that they could purchase the higher quality smallholder tea which was then blended with its own lower quality leaf (KNA/DC/KER/1/32/1950). An agreement was sought with the tea companies to purchase African green leaf for manufacture until the African tea acreage justified the erection of a factory. This applied to the African lands which were found to be adjacent to the established tea factories. As for those African lands that did not lie in the proximity to existing tea factories, the aim of the government was to establish tea factories with the resources from the Government or by soliciting funds from commercial sources like Central Development Agency (KNA/DC/1/30/KER /1950).

Table 1 below shows the acres of planted smallholder tea in Konoin compared to other areas between the years 1957 and 1962.

Table1. Acres of Planted Smallholder Tea in Konoin Relative to other areas (1957-1962)

\begin{tabular}{|c|c|c|c|c|}
\hline Year & Belgut & Bureti & Konoin & Bomet \\
\hline 1957 & - & & 35.33 & - \\
\hline 1958 & - & 9.66 & 39.00 & - \\
\hline 1959 & 9.00 & 16.00 & 44.00 & - \\
\hline 1960 & 32.66 & 26.33 & 64.66 & 5.00 \\
\hline 1961 & 72.00 & 82.92 & 75.54 & 7.06 \\
\hline 1962 & 86.83 & 110.92 & 117.66 & 8.83 \\
\hline
\end{tabular}

Source: KNA/ Nyanza Province/SCDA, Report for Kericho District

From the table above, it can be concluded that smallholder tea production was introduced to Konoin in the year 1957. The residents of Konoin adopted smallholder tea production within the same year. This was done by putting 35.33 acres of land under tea. By 1958, Konoin had increased the land under 
tea from 35.33 acres to 39.00 acres. This was the year when Bureti took up production by putting 9.66 acres of land under smallholder tea production. By 1959, Konoin smallholders were progressively increasing the land under tea production by having 44.00 acres of land under tea production. It was during the same year that Belgut started smallholder tea production by growing tea on 9.00 acres of land. Bomet by this time had not begun adopting smallholder tea production.

By 1960, Konoin stood remarkably as the leading smallholder tea producer in terms of the number of acres of land under tea. The land under smallholder tea production in Konoin stood at 64.66 Bureti had 26.33, Belgut 32.66 while Bomet was beginning with 5.00 acres. In 1961, Bureti District overtook Konoin as it had 82.92 acres of land under tea while Konoin stood at 75.54 acres. Bomet district was lagging behind Belgut. By 1962, Konoin took the lead again by increasing the land under tea to 117.66 acres followed by Bureti with 110.92 acres and Bomet trailing behind with only 8.83 acres. Therefore it can be deduced from the table that smallholder tea production was adopted in 1957 in Konoin and the production increased tremendously in the years that followed. Comparatively, it can be noted from the table that there was remarkable increase in acreage under smallholder tea in Konoin than the other areas (KNA/Nyanza Province/SCDA, Report for Kericho District).

The Swynnerton Plan set a precedent for future land tenure policy that legitimized differential access to land. Land planning which was advocated for by the department of Agriculture after land consolidation affected food crop production. Tea was allocated the largest and the most fertile land. It is important to note that Swynnerton plan outlined a plan to grow cash crops but none for food crop production (Elkins, 2005). This greatly affected the production of food crops especially maize which had become an important crop replacing millet. During the period of consolidation, various aspects of pre-capitalist mode of production like communal system of land ownership were abolished. This subordinated the pre-capitalist modes. It paved way for economic disparities among the Kenyan peasants, the Kipsigis of Konoin, Bomet County included. Maloba (1993) observed that in Kipsigisland, the Swynnerton Plan resulted in tea becoming an important cash crop compared to maize. This means that tea was regarded as a component in the proposed diversification of African agriculture. Chiefs were used to mobilise people to plant tea (Personal Communication, Soi, 2013).

\subsection{The Consequences of Smallholder Tea Farming on Food Crop Production in Konoin (1957- 1963)}

There were several factors that influenced people to adopt the new crop in Konoin. Those who were working for the Europeans saw the benefits of tea and therefore decided to adopt the crop (Personal Communication, Tobon, 2013). However, others got the encouragement from the settlers, while others got motivated by those who had adopted it earlier. What can be said to have been the most pressing factor were very attractive prices for tea and the constant payment made on tea which made the farmers to start growing it in their farms (Personal Communication, Langat, 2013).

After adopting tea, most of the smallholder tea producers realised the benefits. Tea seedlings were made available making it possible for people to expand their land under tea (Personal Communication, Siele, 2013). Most of the informants in the area confirmed that they had to abandon other economic activities to give way to tea production. Some stopped producing maize and keeping cattle because tea demanded a lot of land, labour, and time. The Government of Kenya added to this by encouraging people to increase land under tea (Personal Communication, Siele, 2013). This was done by giving loans, establishing nurseries, improving transport and subsidising inputs, among others. These factors encouraged the farmers to continuously increase the land under tea. While this was going on, little land was left for food crop production (Personal Communication, Langat, 2013).

Smallholders with large pieces of land allocated a major portion of their land to cash crop production (Personal Communication, Serem, 2013). Putting too much land under tea production led to neglect of other income generating activities. Tea also demanded a lot of labour and this made the farmers to devote all their time to it at the expense of the other economic activities. Invariably, the family labour which was commonly used was forced to spend all the time in tea production and food production was neglected. Farmers also took too much time in the buying centres waiting for lorries to collect the tea leaf (Personal Communication, Sofia, 2013). A lot of time spent by a farmer at the collection centres affected food production. In addition, time required to carry out other income generating activities reduced leading to food insecurity. Since people would be forced to depend on the market for food, any calamity or market forces that affected cash crop performance made the farmers to suffer food 
insecurity. This was because they did not grow their own food crops and any changes in market prices affected them (Lappe, 1977).

In Konoin, tea competed for land with food crops such as maize. There was also competition between food crops and smallholder tea production for labour as people gave more attention to cash crop production. This had an implication on food security. The study established that there was a remarkable decline in food production evidenced by the reduction in farm size under maize and other food crops. There was also a reduction of land under livestock production. All these had an implication on food security especially among the smallholder tea producers. It was noted from the study that none tea producers offered their labour to tea producers which on the other hand reduced the time spent in their own farms in producing food crops. This aspect also contributed to food insecurity (Personal Communication, Bommet, 2013). It was also observed during the study that there were many maize traders in the area from the neighbouring Districts. One informant also said that they relied mostly on the maize from the market brought by traders.

Smallholder tea production increased the rate of articulation of the modes of pre-capitalist modes of production into capitalism. The capitalist mode of production was slowly replacing the indigenous modes as more land was put under tea. Every year that passed there was a reduction of land under food production and an increase in the area under tea (Personal Communication, Soi, 2013). This was an indication of dominance of the capitalist mode of production. As the smallholders of Konoin began to concentrate on labour intensive production of tea, they began to depend on tea at the expense of other economic production. This means that the adoption of tea was a step towards depending on cash crop production among the Kipsigis of Konoin.

\section{CONCLUSION}

As established in the study, the introduction of smallholder tea production in Konoin started following pilot scheme that was initiated in 1954 after the promulgation of Swynnerton Plan. Consequently, Africans were allowed to put one third of an acre of their land under tea at the start. The two companies, James Finlay and Brooke Bond, played a key role in the introduction and shaping of African Smallholder tea production in Konoin, Bomet County. This was because before tea could be grown, the companies were expected to give their consent with regard to quality of leaf required and times of delivery. The early tea growers sold their leaf to the tea estate companies. The Kipsigis had mixed reactions to this new crop. Some smallholders adopted tea production because of the experience they acquired from working in the tea estates and hoped that they would get financial returns. Konoin adopted tea production and increased the land under tea in the years 1957 to 1963. This demonstrated that the Pre-capitalist mode of production was even more integrated into the capitalist mode of production in Konoin. Tea was beginning to replace the indigenous crops while the people of Konoin were becoming commodity producers. It has also been established that as the Kipsigis of Konoin put more of their land and labour into smallholder tea production, the land under food crop production was getting smaller and smaller. This affected food crop production as they were made to rely on tea as a source of income. Their modes of production were getting articulated as they were drawn into depending on cash crop production as a source of income.

\section{RECOMMENDATIONS}

Based on the findings of the study, it is recommended that there is a need for the Ministry of Agriculture to encourage smallholder tea producers to diversify activities outside the farm in order to improve their welfare. This can be done by ensuring that the prices of other crops like maize and milk are increased to encourage the farmers to grow maize and keep cattle. Strategies need to be developed to increase the value of food production per unit of land in order to improve food security and living standards. This is in line with the Kenya Vision 2030 development blueprint. There is equally a need to save costs in order to benefit the smallholders. Further study should also be conducted on the irregular prices of tea in the international market.

\section{REFERENCES}

[1] East African Standard (1960, August 12).

[2] East African Standard (1960, July 15).

[3] Eden, T. (1965). 'Tea' Great Britain. London: Western Printing Services.

[4] Elkins, C. (2005). Britain's Gulag: The Brutal end of Empire in Kenya. London: Jonathan Cape. 
[5] Isaacman, A. (1996). Cotton is the mother of poverty, Peasants, work and Rural Struggle in Colonial Mozambique, 1938-1961. Cape Town: David Philip Publishers.

[6] Kabura, E. (2005). Small holder Tea and Coffee Production and its impact on Food Production and living standards in Kenya. Conference on International Research for Development Hohenhelm.

[7] Kenya National Bureau of Statistics (KNBS) (2010). National Census. Nairobi: KNBS.

[8] KNA/AGR/KSM/2/9/1957. SCDA Report for Kericho District, 1957.

[9] KNA/AGR/KSM/1954. Kisumu District Annual Report, 1954.

[10] KNA/DC/KER/1/25/1952. Kericho District Annual Report, 1952.

[11] KNA/DC/KER/1/30/1930. Kericho District Annual Report, 1930.

[12] KNA/DC/KER/1/30/1957. Kericho District Annual Report, 1957.

[13] KNA/NYANZA/2/9/1957. SCDA Report, 1957.

[14] KNA/TBK/1950. Tea in Kenya, 1950.

[15] Kori, K. M., (1976). Tea plantation economy in Kericho District and related phenomena to circa 1960 (BA Dissertation). University of Nairobi, Kenya.

[16] Langat, B. K., Ngenno, V. K., Sulo, T. K., Nyangweso P. M., Korir, M. K., Kipsat, M. J., \& Kebenei, J. S. (2011). Household food security in a commercialized subsistence Economy: A case of Smallholder tea farmers in Nandi South District, Kenya. Journal of Development and Agricultural Economics, 3, 201-209.

[17] Lappe, F. M. (1977). Food First, Beyond the Myth of scarcity. Boston: Houghton Mifflin.

[18] Leys, C. (1994). Underdevelopment of Kenya. Nairobi: East African Educational Publishers.

[19] Lipscomb, J. F., \& Winston, C. (1972). The History of Kenya Agriculture. Nairobi: University Press of Africa.

[20] MacKenzie, F. D. (1999). Betterment and the Gendered Politics of Maize Production Murang'a District Central Province, Kenya, 1880-1952. Canadian Journal of African Studies, 33(1): 64-97.

[21] Maloba, W. (1993). Mau Mau and Kenya: An Analysis of a Peasant Revolt. London: James Currey.

[22] Njiru, A. J. M. (1982). Ushirika Ernbu. A paper on Embu Oisticts cooperative Union presented to Mount Kenya Diocesan Accounts Clerk.

[23] Njogu, W. E. (2002). Household food security and nutritional status of children in Tea and non-tea producing households in Ndia Division Kirinyaga District (Unpublished MA Thesis). Kenyatta University, Nairobi, Kenya.

[24] Ochieng, W. R. (1989). Modern History of Kenya 1895-1980. Nairobi: Evans Brothers.

[25] Ochieng, W. R., \& Ogot, B. A. (1995). Decolonization and independence in Kenya, 1940-1993. Nairobi: East African Educational Publishers.

[26] Odhiambo, W. J., Nyangito, H. O., \& Nzuma, J. (2004). Sources and determinants of Agricultural Growth and productivity in Kenya. KIPPRA Discussion paper No 3.

[27] Odingo, R. S. (1971). The Kenya Highlands: Landuse and Agricultural development. Nairobi: East African Publishing House.

[28] Omwoyo, S. M. (2000). The Agricultural Changes in Kipsigisland 1894-1963: An Historical Inquiry (Ph.D. Thesis). Kenyatta University, Nairobi. Kenya.

[29] Ongile, G. A., (1996). Gender and Agricultural supply Response to Structural Adjustment Programmes: A case study of smallholder Tea Producers in Kericho, Kenya. Kenyatta University, Nairobi, Kenya.

[30] Swainson, N. (1980). The development of Corporate Capitalism in Kenya, 1918-1977. L London, Nairobi: Heinemann.

[31] Swynnerton, R. (1954). A plan to Intensify the Development of African Agriculture in Kenya. Nairobi: Government Printers.

\section{AUTHORS' BIOGRAPHY}

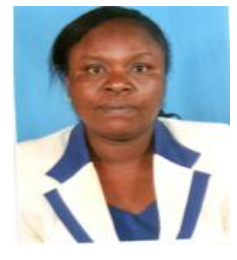

Fancy Chepkemoi Chepkwony born in 1971 and acquired Kenyan citizenship by birth. She is a Christian and married. She started her primary education at St. Peters in Nandi County and managed to get a Certificate of Primary education in 1983. She later joined Kipsigis Girls in 1984 to 1987 for my Kenya Certificate of Secondary Education.

After which she proceeded for an Advanced Level certificate from 1988 to 1989 at Kipsigis Girls. She got Kenya Advanced Certificate of Education (KACE). Having completed her Advanced level I qualified to join University of Nairobi for a Bachelors of Education Arts (History and Religious 
Studies). She completed her undergraduate degree in 1993 with and got employed by the Teachers Service Commission as a secondary school teacher stationed in Kaptebeswet as from 1994 to 2002 where she was transferred to Kericho Teachers Training College as a tutor.

In 2008, she enrolled for a Masters Degree Programme at Kenyatta University to pursue Master of Arts History and graduated in August 2017. she wrote her thesis on small-holder tea production in Kenya, a case of Bomet County.

Citation: Chepkemoi Kirui Fancy C. "Effect of Smallholder Tea Growing on Food Crop Production in Bomet County, Kenya, 1954-1963". International Journal of History and Cultural Studies (IJHCS). vol 4, no. 4, 2018, pp. 68-78. doi: DOI: http://dx.doi.org/ 10.20431/2454-7654.0404006.

Copyright: () 2018 Authors. This is an open-access article distributed under the terms of the Creative Commons Attribution License, which permits unrestricted use, distribution, and reproduction in any medium, provided the original author and source are credited. 